\title{
Risk management in automotive manufacturing process based on FMEA and grey relational analysis: A case study
}

\author{
Baynal, K..$^{a,}{ }^{,}$, Sarı, T. ${ }^{b,{ }^{*}}$, Akpınar, B. ${ }^{c}$ \\ ${ }^{a}$ Kocaeli University, Department of Industrial Engineering, Kocaeli, Turkey \\ ${ }^{b}$ Konya Food and Agriculture University, Department of International Trade and Business, Konya, Turkey \\ ${ }^{\mathrm{c}}$ General Electric, İstanbul, Turkey
}

\begin{abstract}
A B S T R A C T
Risk management is an important issue in manufacturing companies in today's competitive market. Failure modes and effects analysis (FMEA) method is a risk management tool to stabilize production and enhance market competitiveness by using risk priority numbers (RPN). Although the traditional FMEA approach is an effectively and commonly used method, it has some shortcomings such as assumption of equal importance of the factors, severity, occurrence and detectability, and not following the ordered weighted rule. Thus, in order to improve RPN, an integrated method combining grey relational analysis (GRA) with FMEA is used in this study. The purpose of this paper is to contribute to risk management activities by proposing solutions to assembly line problems in an automotive manufacturing company by using combined GRA and FMEA method. In the proposed method, the priorities of production failures were determined by GRA approach and these failures were minimized by using FMEA technique. The study results indicated the actions that lead to enhancement in the product. The implementation of corrective/preventive activities resulted in $96 \%$ improvement in door seal cuts problem caused by the door step assembly. Door seal cuts problem caused by instrument panel assembly and the noisy door window problem are solved completely.
\end{abstract}

\author{
ARTICLE INFO \\ Keywords: \\ Automotive manufacturing; \\ Risk management; \\ Failure modes and effect analysis \\ (FMEA); \\ Grey relational analysis (GRA) \\ *Corresponding author: \\ tugba.sari@gidatarim.edu.tr \\ (Sarl, T.) \\ Article history: \\ Received 12 July 2017 \\ Revised 16 January 2018 \\ Accepted 20 February 2018
}

\section{References}

[1] Stamatis, D.H. (2003). Failure mode effect analysis: FMEA from theory to execution, 2nd edition, ASQ Quality Press, Wisconsin, USA.

[2] Pillay, A., Wang, J. (2003). Modified failure mode and effects analysis using approximate reasoning, Reliability Engineering \& System Safety, Vol. 79, No. 1, 69-85, doi: 10.1016/S0951-8320(02)00179-5.

[3] Chang, K.H., Chang, Y.C., Tsai, I.T. (2013). Enhancing FMEA assessment by integrating grey relational analysis and the decision making trial and evaluation laboratory approach, Engineering Failure Analysis, Vol. 31, 211-224, doi: 10.1016/i.engfailanal.2013.02.020.

[4] Vinodh, S., Santhosh, D. (2011). Application of FMEA to an automotive leaf spring manufacturing organization, The TQM Journal, Vol. 24, No. 3, 260-274, doi: 10.1108/17542731211226772.

[5] Yazdi, M., Daneshvar, S., Setareh, H. (2017). An extension to fuzzy developed failure mode and effects analysis (FDMEA) application for aircraft landing system. Safety Science, Vol. 98, 113-123, doi: 10.1016/j.ssci.2017.06. $\underline{009}$.

[6] Chang, K.H. (2016). Generalized multi-attribute failure mode analysis, Neurocomputing, Vol. 175, Part A, 90-100, doi: 10.1016/j.neucom.2015.10.039. 
[7] Segismundo, A., Miguel, P.A.C. (2008). Failure mode and effects analysis (FMEA) in the context of risk management in new product development: A case study in an automotive company, International Journal of Quality \& Reliability Management, Vol. 25, No. 9, 899-912, doi: 10.1108/02656710810908061.

[8] Banduka, N., Veža, I., Bilić, B. (2016). An integrated lean approach to process failure mode and effect analysis (PFMEA): A case study from automotive industry, Advances in Production Engineering \& Management, Vol. 11, No. 4, 355-365, doi:10.14743/apem2016.4.233.

[9] Liu, H.C., Li, P., You, J.X., Chen, Y.Z. (2015). A novel approach for FMEA: Combination of interval 2-tuple linguistic variables and gray relational analysis, Quality and Reliability Engineering International, Vol. 31, No. 5, 761-772, doi: $10.1002 /$ gre.1633.

[10] Liu, H.C., You, J.X., Li, P., Su, Q. (2016). Failure mode and effect analysis under uncertainty: An integrated multiple criteria decision making approach, IEEE Trnasactions on Reliability, Vol. 65, No. 3, 1380-1392, doi: 10.1109/TR. 2016.2570567.

[11] Borković, J., Milčić, D., Donevski, D. (2017). Implementation of differentiated quality management system and FMEA method in the newspaper production, Tehnički Vjesnik - Technical Gazette, Vol. 24, No. 4, 1203-1211, doi: $10.17559 / \mathrm{TV}-20160222082713$.

[12] Feng, C.M., Wang, R.T. (2000). Performance evaluation for airlines including the consideration of financial ratios, Journal of Air Transport Management, Vol. 6, No. 3, 133-142, doi: 10.1016/S0969-6997(00)00003-X.

[13] Hsu, C.I., Wen, Y.H. (2000). Application of grey theory and multi objective programming towards airline network design, European Journal of Operational Research, Vol. 27, No. 1, 44-68, doi: 10.1016/S0377-2217(99)00320-3.

[14] Lin, J.L., Lin, C.L. (2002). The use of the orthogonal array with grey relational analysis to optimize the electrical discharge machining process with multiple performance characteristics, International Journal of Machine Tools and Manufacture, Vol. 42, No. 2, 237-244, doi: 10.1016/S0890-6955(01)00107-9.

[15] Wang, P., Meng, P., Zhai, J.Y., Zhu, Z.Q. (2013). A hybrid method using experiment design and grey relational analysis for multiple criteria decision making problems, Knowledge-Based Systems, Vol. 53, 100-107, doi: 10.1016/j.knosys.2013.08.025.

[16] Palanikumar, K., Karunamoorthy, L., Karthikeyan, R. (2006). Multiple performance optimization of machining parameters on the machining of GFRP composites using carbide (K10) tool, Materials and Manufacturing Processes, Vol. 21, No. 8, 846-852, doi: 10.1080/03602550600728166.

[17] Rajeswari, B., Amirthagadeswaran, K.S. (2017). Experimental investigation of machinability characteristics and multi-response optimization of end milling in aluminium composites using RSM based grey relational analysis, Measurement, Vol. 105, 78-86, doi: 10.1016/j.measurement.2017.04.014.

[18] Wang, Y.J. (2009). Combining grey relation analysis with FMCGDM to evaluate financial performance of Taiwan container, Expert Systems with Applications, Vol. 36, No. 2, Part 1, 2424-2432, doi: 10.1016/j.eswa.2007.12.027.

[19] Ramesh, S., Viswanathan, R., Ambika, S. (2016). Measurement and optimization of surface roughness and tool wear via grey relational analysis, TOPSIS and RSA techniques, Measurement, Vol. 78, 63-72, doi: 10.1016/ j.measurement.2015.09.036.

[20] Baghery, M., Yousefi, S., Rezaee, M.J. (2016). Risk measurement and prioritization of auto parts manufacturing processes based on process failure analysis, interval data envelopment analysis and grey relational analysis, Journal of Intelligent Manufacturing, Vol. 1, 1-23, doi: 10.1007/s10845-016-1214-1.

[21] Chan, J.W.K., Tong, T.K.L. (2007). Multi-criteria material selections and end-of-life product strategy: Grey relational analysis approach, Materials \& Design, Vol. 28, No. 5, 1539-1546, doi: 10.1016/j.matdes.2006.02.016.

[22] Deng, J.L. (1989). Introduction to grey system theory, The Journal of Grey System, Vol. 1, No. 1, 1-24.

[23] Zhai, L.Y., Khoo, L.P., Zhong, Z.W. (2009). Design concept evaluation in product development using rough sets and grey relation analysis, Expert System with Applications, Vol. 36, No. 3, Part 2, 7072-7079, doi: 10.1016/ j.eswa.2008.08.068.

[24] Wu, H.H. (2002). A comparative study of using grey relational analysis in multiple attribute decision making problems, Quality Engineering, Vol.15, No. 2, 209-2017, doi: 10.1081/QEN-120015853. 